
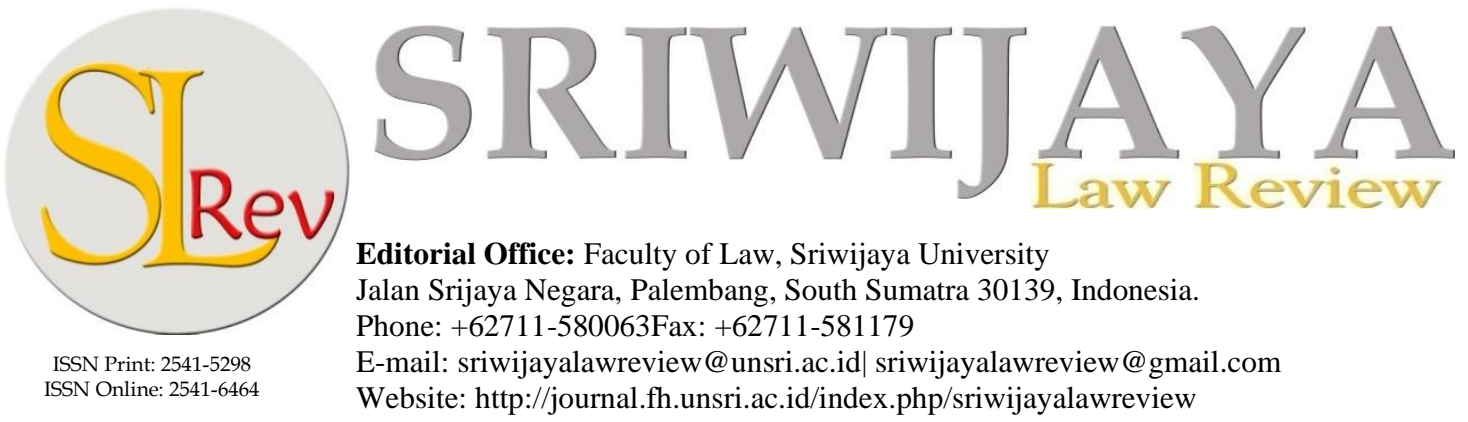

Editorial Office: Faculty of Law, Sriwijaya University

Jalan Srijaya Negara, Palembang, South Sumatra 30139, Indonesia.

Phone: +62711-580063Fax: +62711-581179

E-mail: sriwijayalawreview@unsri.ac.id| sriwijayalawreview@gmail.com

Website: http://journal.fh.unsri.ac.id/index.php/sriwijayalawreview

\title{
The Patent System During Global Pandemic and the Access to Medications and Vaccines
}

\author{
Fatou Diagne Mbaye, ${ }^{\mathrm{a}}$ and Agus Sardjono ${ }^{\mathrm{b} *}$
}

a Faculty of Law, Universitas Indonesia, Indonesia. E-mail: fatoudiagnembaye94@ gmail.com

$b^{*}$ Faculty of Law, Universitas Indonesia, Indonesia. Corresponding Author Agus Sardjono, email: agussardjono@yahoo.com

\begin{tabular}{|c|c|}
\hline Article & Abstract \\
\hline 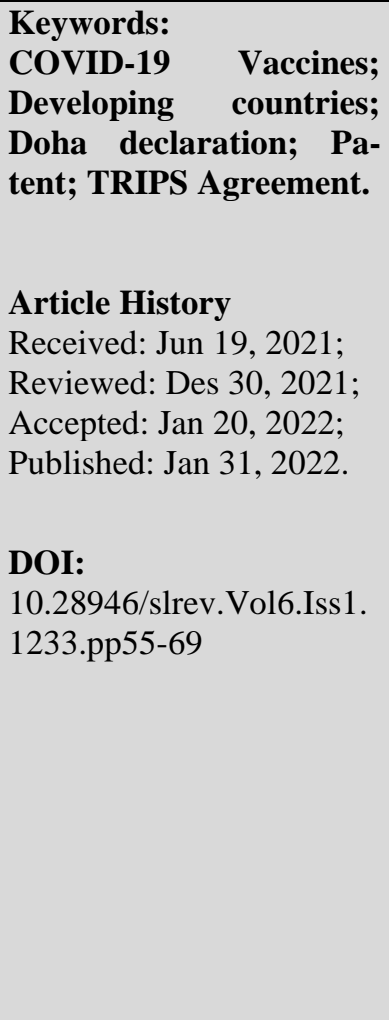 & $\begin{array}{l}\text { The Declaration on Trade-Related Intellectual Property Rights (TRIPS) and } \\
\text { Public Health Agreements want to promote the balanced interpretation and } \\
\text { implementation of its provisions and promote universal access by assisting } \\
\text { WTO members to protect public health rights. Two years will soon pass, and } \\
\text { the emergence of new variants of COVID-19 shows that the virus will not } \\
\text { stop at national borders. However, vaccines are gradually entering and almost } \\
\text { monopolised by industrialised countries. If Jonas Salk thought in the 1950s } \\
\text { that patenting his polio vaccine was like patenting the sun, the problem } \\
\text { appearing is that today's patent holders do not think so. The COVID-19 } \\
\text { vaccine is owned by biotech companies, universities, research institutes or } \\
\text { pharmaceutical companies. The purpose of this research is to analyse, through } \\
\text { a normative juridical approach, the requirement for patent holders to protect } \\
\text { their intellectual property rights if they are to remain competitive in the } \\
\text { marketplace. Not to forget that they must pay patent fees as a percentage of } \\
\text { the final price of the vaccine, which is a significant benefit to the economies } \\
\text { of the countries where they are located. While for developing countries, the } \\
\text { best solution would be to produce their vaccines. With industrial property } \\
\text { rights, it seems impossible to transfer the vaccine technology on COVID-19. } \\
\text { That is why some developing countries (South Africa and India have the } \\
\text { support of many other developing countries) have filed a complaint with the } \\
\text { WTO, requesting a waiver of property rights under Article } 31 \text { of TRIPS in } \\
\text { order to produce a COVID-19 vaccine on a large scale and at an affordable } \\
\text { price. }\end{array}$ \\
\hline
\end{tabular}

(O2022; This is an Open Access Research distributed under the term of the Creative Commons Attribution License (https://Creativecommons.org/licences/by/4.0), which permits unrestricted use, distribution, and reproduction in any medium, provided the original works is properly cited.

\section{INTRODUCTION}

When a drug or vaccine proves that it can prevent viral infections, it can be protected by the patent system granted to its inventor. The patent is an industrial property right that legally protects inventions, such as objects, molecules or chemical reactions. It is geographically and temporally 
limited and lasts 20 years. The patent right essentially includes an exclusive right, which gives the inventor money or property rights. For the inventor, it includes: 1) Using the subject matter of the invention or the process; 2) Authorising one or more persons to exploit it at their place or at the same time; 3 ) Transferring purely and simply his rights to a third party.

A patent is a title granted by a State or an international organisation that grants an inventor or successor in the provisional title exploitation of an invention. A patent is a title granted by the State or an international organisation, which gives the inventor or his successors a temporary monopoly of exploitation on an invention. Patents are granted for new inventions that involve an inventive step and are susceptible to industrial application. Annexe 1 to the Bangui Agreement establishing the African Intellectual Property Organization defines an invention, in its article 1, as "an idea that permits a specific problem in the field of technology to be solved in practice". ${ }^{1}$

The international patent system is governed by the Agreement on Trade-Related Aspects of Intellectual Property Rights (TRIPS). In principle, a patent holder has an exclusive right to his invention. It gives him the right to prevent third parties acting without his consent from making, using, offering for sale, selling or importing for these purposes the invented product or the product obtained directly by the process if the patent is a process (Article 28, paragraph 1 of the TRIPS Agreement). However, at the fifty-second World Health Assembly, a new resolution on the revised pharmaceutical strategy was recognised (resolution WHA 52.19) in which the World Health Organization asks its member states to "ensure that public health interests are paramount in pharmaceutical and health policies". ${ }^{2}$ In 2000, more than $40^{3}$ pharmaceutical companies sued the South African government for the use of WHO and WTO-recommended benefits under the TRIPS Agreement in their national law. The discussions initiated by the WTO on this subject led to the Doha Declaration. It would therefore be interesting in the following lines to broaden the problem: 1) what are the origin of the patents?; 2) how are the patents governed in the TRIPS agreement; and 3) how to allow developing and least developed countries to produce their vaccines essentially or to access generic vaccines in order to bypass the cost of current vaccines, especially during the current pandemic of COVID-19 whose death toll exceeds 3 million to date?

The research method used in this article is a legal-descriptive and normative approach that is applied to examine the WTO legal instruments, more specifically the TRIPS Agreement and other relevant legal instruments and their interpretation such as the Doha Declaration on Public Health.

The study is essentially a library-based one involving a thorough literature survey. The data sources used are legal materials, with their primary sources taken mainly from the TRIPS Agreements and the Doha Declaration on Public Health. The secondary sources are books, journals, and articles. The tertiary sources are from the Black Law Dictionary.

This study aims to gain a deep and constructive understanding of the fact that an advanced application of the TRIPS Agreement and the Doha Declaration on Public Health could constitute a central point for better access to medicines and vaccines by developing countries.

1 Annexe I Patents Title I General Provisions, "African Intellectual Property Organization (OAPI) Bangui Agreement" (n.d.).

2 World Health (WHO) Organization, "Fifty-Second World Health Assembly," Fifty-Second World Health Assembly, Geneva, 17-25 May 1999: Verbatim Records of Plenary Meetings and List of Participants. 52, no. 8649 (1999): 26.

3 Pat Sidley, "Drug Companies Sue South African Government over Generics," BMJ 24, no. 332 (2001): 447, https://doi.org/doi: 10.1136/bmj.322.7284.447. 


\section{ANALYSIS AND DISCUSSION Origin of Patents}

In $1474,{ }^{4}$ the modern patents system was developed with the Parte Veneziana law in Venice, Italy. It is the first law to set up the conditions of the law on the patentability of an invention: 1) encouragement of the inventive activity; 2) compensation of the costs incurred by the entrepreneur; 3) the inventor's right to his creation, and 4) above all social utility of the invention. The Parte Veneziana explains that:

"It is consequently promulgated by the authority of this body that whoever in this city makes a new and ingenious machine, which had never before been made within the borders of our jurisdiction, is obliged to register it at the office of the Provveditori di Comun as soon as it has been perfected, so that it may be used. It will be forbidden to any other person in our territory to make another machine identical or similar to this one without the author's agreement or license for ten years. If anyone does so, the author shall have the option of summoning him before any department of this city, which may charge the offender one hundred ducats, whose machine shall be destroyed. However, our government may, if it so desires, confiscate for its own use any machine or instrument, provided that no one other than the authors may use them." 5

Around 1450, the states began to implement a commercial system that encouraged a surplus trade balance. This gave rise to the monopoly granted to inventors or importers of new technologies that encouraged the arrival of foreign industries. At that time, the criteria for an inventor to receive the privilege of a monopoly on his invention was that the invention must not yet be in use ${ }^{6}$ in the country, at the time, the new privilege was granted.

In the 16th century, privileges were received arbitrarily with an obligation to justify the economic or social utility of the inventions. This justification was done outside the rules of the art. In Germany, an imperial privilege of 1545 was issued for an invention whose object was simply described as functional. ${ }^{7}$ In England and France, individuals justified their application because national independence from foreigners would be more critical. ${ }^{8}$ However, here and there, privileges were granted for real inventions. The privileges managed to survive alongside the favouritism that maintained them. Still, during this century, since the applicants had to demonstrate the economic or social utility of the object of their privilege, the Statute of Monopolies was created in $1623 .{ }^{9}$ Its purpose was to dissolve all monopolies in the kingdom except those relating to any new species. Section 6 of the Statute of Monopolies provides an exception for monopolies "contrary to the law nor mischievous to the state by raising prices of

4 Richard L Hindle, "Inventing Venice : An Urban and Environmental Innovation Model from the Lagoon City," UC Berkeley, 2019, 531, https://escholarship.org/uc/item/75635711.

5 Olia i Klod, "Pour Tout Savoir Sur Venise, Le Carnaval Vénitien et Les Costumé-E," 2011, https://oliaklodvenitiens.wordpress.com/2011/03/19/parte-veneziana/.

6 Serge Lapointe, “L’histoire Des Brevets,” 2000, https://www.lescpi.ca/s/1972.

7 Gabriel Galvez-behar L Etat and Gabriel Galvez-behar, "L'Etat et l'invention. Une Comparaison FrancoAllemande Des Cadres de La Propriété Industrielle à La Fin Du XIXè Siècle.," 2010, 34, https://halshs.archivesouvertes.fr/halshs-00010217/document.

8 Etat and Galvez-behar.

9 Émilie Bouchet-Le Mappian, "Intellectual Property and Property Law in English, German and French Law. In French; Propriété Intellectuelle et Droit de Propriété En Droits Anglais, Allemand et Français," Presses universitaires de Rennes (Presses universitaires de Rennes, 2013). 
commodities at home, or hurt of trade, or generally inconvenient." ${ }^{, 10}$ It is this clause which inspired the Australian patent law ${ }^{11}$ that could constitute an exclusion from patentability for medicines.

In the United States of America, some colonies had already adopted patent laws. The Constitution of 1788 adds the moral right in the American Constitution where it can be found in Article 1, Section 8, paragraph 8. It stated that one of the attributes of Congress is to be able to "The Congress shall have power: To promote the Progress of Science and useful Arts, by securing for limited Times to Authors and Inventors the exclusive Right to their respective Writings and Discoveries". ${ }^{12}$

The internationalisation of intellectual property rules marks the end of the 19th century. The purpose of patent conventions and treaties is essential to extend the rights that a State grants to its citizens to the citizens of other States through national treatment. Patentability and patent administration remain national issues, meaning that states have the ability to exclude drugs from patentability.

\section{The Exclusion of Pharmaceutical Products from Patent Protection}

It may be assumed that countries have always issued their patent laws according to their economic development. As early as the 19th century, the French in 1844 and Germany in 1877 excluded pharmaceutical products from patentability. ${ }^{13}$ Only after the pharmaceutical industries became quite developed did some countries reinstate protection in the pharmaceutical field. Thus, this reinstatement took place in 1960 in France, in 1968 in Germany, in 1976 in Japan, in 1977 in Switzerland and $1978^{14}$ in Italy. Today, these countries are all among the top 20 exporters of pharmaceutical products. ${ }^{15}$ In fact, it can be stated that until 1989, pharmaceutical products were not patentable in many of the countries that signed the Paris Convention for the Protection of Intellectual Property. ${ }^{16}$

10 "England's Statute of Monopolies of 1623 (21 Jac. 1, c.3), While Generally Condemning Monopolies, Provided the True and First Inventor of a given Item up to Fourteen Years of Exclusive Rights to Their Invention, Provided That: ..." they Be Not Contrary to T" (n.d.), https://en.wikisource.org/wiki/Statute_of_Monopolies .

11 D Nicol O Mitnovetski, "Are Patents for Methods of Medical Treatment Contrary to the Ordre Public and Morality or 'Generally Inconvenient'?," Journal of Medical Ethics 30, no. 5 (2004): 470, https://doi.org/10.1136/jme.2002.000786.

12 Gordon F. Henderson, "Patent Law of Canada, (Toronto, Carswell, 1997)" (1997).

13 Maurice Cassier, "Industrial Property and Public Health. Project Magazine, Centre for Social Research and Action; in French, Pro-Priété Industrielle et Santé Publique. Revue Projet, Centre de Recherche et d'action Sociales (C.E.R.A.S )" 270, no. 2 (2002), https://halshs.archives-ouvertes.fr/halshs-01893992/document.

14 S. Salazar, "Panel Discussion on Intellectual Property and Human Rights, Organised by the World Intellectual Property Organization Intellectual Property Organization (WIPO) Geneva," Intellectual Property and the Right to Health, no. 762 (1999): 65-91, 71.

15 WTO, "Statistical Review of World Trade 2020," Figure 4.34 Top 20 exporters of chemicals and pharmaceuticals, 2016, https://www.wto.org/french/res_f/statis_f/wts2016_f/wts2016_f.pdf .

16 TRIPS and pharmaceutical patents Mfuka Claude, "The Difficult Access of Developing Countries to AIDS Drugs Page 194, in French Accords ADPIC et Brevets Pharma-Ceutiques: Le Difficile Accès Des Pays En Développement Aux Médicaments Antisida. In," Revue d'économie Industrielle 99, no. 2 (2002): 191-214. 


\section{The Advent of the TRIPS Agreement}

In the 1980s, intellectual property rights became essential topics of international economic negotiations. ${ }^{17}$ This is due to the unprecedented economic internationalisation that started in this period and the development of easily reproducible technologies.

The companies from developed countries were active in the areas most affected by counterfeiting that demanded a strengthening of the international intellectual property protection regime. Therefore, the United States, supported by the European Communities, Japan and Switzerland, started international negotiations to strengthen the international intellectual property protection regime. At that time, the forum for discussions on intellectual property was the World Intellectual Property Organization ${ }^{18}$ (WIPO). However, the revision of the General Agreement on Tariffs and Trade (GATT) seemed to offer more opportunities for industrialised countries because of its more binding dispute settlement procedure, its power to address the issue in global trade negotiations, and also because developing countries had less power ${ }^{19}$ as a group.

For Southern countries, considering intellectual property protection within the GATT was apparently not an option. They expressed their concerns during an official meeting of the Negotiating Group on the subject. They were concerned about the possible over-protection of intellectual property, which could increase the cost of medicines. ${ }^{20}$ In fact, developing countries wanted to keep WIPO as a forum, which would have allowed them to separate the issue of intellectual property protection from other trade issues. Intellectual property was seen by these countries as a type of technological protectionism, allowing the protection of the global market in favour of the owners of high-tech innovations. ${ }^{21}$

\section{Provisions of the TRIPS Agreement concerning the Pharmaceutical Field}

The Uruguay Round of negotiations from 1986 to 1994 and the birth of the WTO led to the accession of several States to a series of multilateral sectorial conventions, including the TRIPS Agreement. The negotiators of the TRIPS Agreement decided to update the rules of the preexisting international regime for the protection of intellectual property rather than reinventing them but adding a touch of novelty ${ }^{22}$ that strengthens the protection of intellectual and industrial property, such as the obligation to protect finished products.

\section{The Obligation to Protect the Finished Products}

Reverse engineering is one of the techniques used by generic drug manufacturers in countries that allow it. This technique consists of implementing a manufacturing technique from a finished

17 Desterbecq H. et B. Remiche, "Pharmaceutical Patents in the GATT Agreements: What Is at Stake? Page 18, in French Les Brevets Pharmaceu-Tiques Dans Les Accords Du GATT: L'enjeu?, Revue Internationale de Droit Économique, X (1)" (1996).

18 Dirk De Bièvre Lars Thomann, "Forum Shopping in the Global Intellectual Property Rights Regime, Arbeitspapiere - Working Papers Nr. 132, Mannheimer Zentrum Für Europäische Sozialforschung” (2010).

19 Remiche, pharmaceutical patents in the GATT agreements: what is at stake? page 18, in french Les brevets pharmaceu-tiques dans les accords du GATT : l'enjeu ?, Revue internationale de droit économique, X (1).

20 D. Gervais, "The TRIPS Agreement: Drafting History and Analysis, Londres, Sweet \& Maxwell” (1998).

21 Desterbecq H. et B. Remiche, “Les Brevets Pharmaceutiques Dans Les Accords Du GATT: L'enjeu?, Revue Internationale de Droit Économique, X (1)" (1996).

22 TRIPS Agreement, “Article 27,” n.d. 
product. ${ }^{23}$ Reverse engineering is legally possible in countries where the patent system protects only the process and not the finished product. In these states, a generic pharmaceutical manufacturer can use a finished pharmaceutical product that a patent may protect to develop its manufacturing process and thus legally produce the same product.

Unfortunately, under Article 27 of the TRIPS Agreement, it is not permissible to protect only processes and finished products must also be protected. The original pharmaceutical manufacturers then have the possibility in all WTO Member States to protect their finished products and their processes, making any use of reverse engineering illegal.

"Subject to the provisions of paragraphs 2 and 3, patents may be obtained for all inventions, whether products or processes, in all fields of technology, provided that they are new, involve an inventive step and are capable of industrial application.5 Subject to paragraph 4 of Article 65, paragraph 8 of Article 70, and paragraph 3 of this article, patents may be obtained, and patent rights may be exercised without discrimination as to the place of invention, the field of technology, and whether the products are imported or locally manufactured". ${ }^{24}$

Not only processes patent protection mandatory, but the burden of proof is also reversed in cases of infringement of a process patent under Article 34:

"For the purposes of civil proceedings for infringement of the rights of the owner referred to in paragraph 1(b) of Article 28, if the subject matter of a patent is a process for obtaining a product, the judicial authorities shall have the power to order the defendant to prove that the process for obtaining an identical product is different from the patented process. Accordingly, Members shall provide, in at least one of the following circumstances, that any identical product, when made without the consent of the patent owner, shall, until the contrary is proved, be deemed to have been obtained by the patented process". 25

\section{The Obligation of Non-discrimination in the Field of Technology}

In addition to requiring protection for processes and finished products, Article 27(1) of the TRIPS Agreement prohibits discrimination in the field of technology. This prohibition relates to any recourse to extraordinary measures that member states may wish to limit protection in the pharmaceutical field to protect public health. The question of whether the possibility of limited exceptions to patent rights under Article 30 of the TRIPS was subject to the non-discrimination obligation under Article 27(1) was put to a Panel $^{26}$. The Panel concluded that the antidiscrimination rule in Article 27(1) does apply to exceptions of the kind permitted by the article. In other words, the exceptions must not discriminate against a particular technology field.

\section{The Role of Ex Officio Licenses: Article 31 or the Emergency Exception in the COVID-19 Health Crisis}

A patent license could be defined as a lease contract by which the patent owner grants to a third party the right to exploit an invention, which constitutes all or part of the subject matter of his title, in return for the payment of a royalty. Therefore, the patentee is, in principle, the owner of the property right, free to conclude this contract with whomever he wishes. Exceptionally, in some instances specified by the law, the patentee may be obliged to grant such authorisation of use. This

23 F. Scherer, "The Patent System and Innovation in the Pharmaceutical Field, in French, Le Système Des Brevets et l'innovation Dans Le Domaine Pharmaceutique, Revue Internationale de Droit Economique, N¹” (2000).

24 TRIPS Agreement, "Article 27."

25 TRIPS Agreement, "Article 34."

26 Canada - Patent Protection for Pharmaceutical Products (Complaint by the European Communities and their Member States), (2000) WTO Doc.WT/ DS114/R Panel Report para 4.21 page37. 
is the case of "compulsory" licenses, which impose on the patentee a licensee that he has not chosen. In this case, the patentee must give non-exclusive licenses to those in competition with him and who request it in exchange for a reasonable consideration. If no, the competent authority issues the license in his place.

Article 5 of the Paris Convention for the Protection of Industrial Property already provided that contracting countries could take legislative measures, but only to prevent abuses resulting from the exercise of the patent right, for example, in the absence of exploitation. The TRIPS Agreement now provides, independently of any abuse, conditions under which compulsory licenses may be granted by Members (Article 31 of the TRIPS Agreement). This provision sets clear boundaries for the exception: prior negotiation with the right holder; duration and scope of the license to be strictly limited according to need; non-exclusive and non-transferable nature of the license (except with goodwill); the license granted primarily for the supply of the market of the authorising Member; adequate remuneration of the patentee, subject to judicial review or review by an independent higher authority. Finally, Article 31(1) provides specific conditions for when the license concerns a dependent patent: the invention must involve a significant technical advance and be of considerable economic interest, the owner of the first patent will be entitled to a crosslicense on reasonable terms to use the invention claimed in the second, and the authorised users in connection with the first patent will be non-transferable unless the second patent is also assigned.

\section{The Doha Declaration on Public Health}

The Doha Declaration on Public Health balances the competing interests of pharmaceutical patent holders and users of medicines: "We recognise that intellectual property protection is important for the development of new medicines. We also recognise the concerns about its effects on prices". ${ }^{27}$ This statement is intended to reaffirm the ability of WTO Members to take social welfare and public health issues into account in the development of their intellectual property policies. In an August 2003 decision on the implementation of this paragraph $6,{ }^{28}$ WTO Members removed a vital obstacle to affordable drug imports by lifting the limitation in the TRIPS Agreement that made compulsory licensing conditional on procurement primarily for local ${ }^{29}$ market. The decision explains that if the importing country cannot guarantee access to needed medicines at affordable prices, these medicines could be produced under compulsory license by drug manufacturers in third countries and imported into poorer countries that cannot manufacture their medicines. Two years later, WTO Members agreed in 2005 to permanently incorporate the 2003 waiver decision into the TRIPS Agreement through a protocol. The entry into force of this amendment ensures flexibility to protect public health and is now an integral part of the TRIPS Agreement by being included in Article 31 bis added to its annexe. The system introduced consists of two parallel initiatives: an eligible country applies for and obtains a compulsory license for the import, marketing or distribution of the products in question, provided that a need exists, i.e. that a patent

27 Doha WTO Ministerial, “TRIPS WT/MIN(01)/DEC/2 20 November 2001. Declaration on the TRIPS Agreement and Public Health Adopted on 14 November 2001,” Https://Www.Wto.Org/English/Thewto_E/Minist_E/Min01_E/Mindecl_Trips_E.Htm.

28 WTO, "Protocol Amending the TRIPS Agreement,

WT/L/540," n.d., https://www.wto.org/french/tratop_f/trips_f/implem_para6_f.htm.

29 WTO, "Implementation of Paragraph 6 of the Doha Declaration on the TRIPS Agreement and Public Health, 30 August 2003, WT/GC/M/82," n.d., https://www.wto.org/english/tratop_e/trips_e/implem_para6_e.htm. 
is in force in its territory; a laboratory applies for and obtains a compulsory license for the manufacture and export of medicines. This new system has hardly been used up to now, ${ }^{30}$ certainly because of its complexity. ${ }^{31}$ However, its implementation will have demonstrated the speed and flexibility that the WTO is capable of demonstrating in reforming industrial property on an international scale.

After recalling the importance of intellectual property in promoting access to existing medicines and research and development of new medicines, the declaration on the TRIPS Agreement and Public Health states that the TRIPS Agreement should not prevent Members from taking measures to protect public health. This is a crucial issue for developing countries: access to medicines. Article 8 of the TRIPS Agreement provides that WTO members adopt measures necessary to protect public health. However, at the same time, the TRIPS Agreement requires patent protection for any invention relating to medicine (whether a product or a manufacturing process) for 20 years from the date of filing of the patent application. Developing countries, which do not have the financial means to buy patented medicines, ${ }^{32}$ are therefore claiming the right to use the flexibilities provided for in the TRIPS agreement, in particular in Article 31, which provides for the possibility for a Member State, subject to compliance with certain conditions, ${ }^{33}$ to issue compulsory licenses, allowing the exploitation of a patented product by a third party without the authorisation of the rights holder. The text specifies, however, that recourse to compulsory licenses is only possible in emergency situations or in the case of public use for non-commercial purposes.

In fact, compulsory licensing is seen as a useful tool for countries with weak health systems. So far, India, ${ }^{34}$ Brazil $^{35}$ and South Africa ${ }^{36}$ have led the most effective campaigns for the simplification of the mechanism. The current pandemic is expected to spread the use of the mechanism much more widely, as the examples, we have already seen the show. In March 2020, the Chilean Parliament ${ }^{37}$ unanimously passed a resolution declaring that the global outbreak of COVID-19 justifies the use of compulsory licensing to facilitate access to vaccines, drugs, diagnostics, devices, supplies and other technologies useful for the surveillance, prevention, detection, diagnosis and treatment of people infected with the coronavirus in Chile. Then it was

30 George Tsai, “Canada's Access to Medicines Regime: Lessons for Compulsory Licensing Schemes under the WTO Doha Declaration, 49 VA. J. INT'L L.” (2009).

31 Brin Anderson, "Better Access to Medicines: Why Countries Are Getting 'Tripped' up and Not Ratifying Article 31 Bis, Case Western Reserve Journal of Law, Technology \& the Internet” (2010).

32 V. B. Marre, “Rapport d'information Déposé Par La Délégation de l'Assemblée Nationale Pour l'Union Européenne Sur Le Bilan de La Conférence Ministérielle de l’OMC de Doha, 31 Janv,' 2002. no 3569, p. 22 : le coût annuel d'un traitement individuel contre le SIDA est évalué entre 10000 et 15000 dollars.

33 "The Patent Holder Must Have Refused a Voluntary License," the authorisation is given for the internal market of the Member State that allowed the use; the scope and duration of the authorisation are limited; the compulsory license is not transferable; the patent holder must receive adequate remuneration, etc., n.d.

34 Sandeep K. Rathod, "Compulsory Licences on Pharmaceutical Patents in India: A Short Article," Journal of Generics Medicines 13 (2017): 108.

35 Paul Champ and Amir Attaran, "Patent Rights and Local Working Under the WTO Trips Agreement: An Analysis of the U.S.-Brazil Patent Dispute," Yale Journal of International Law 27 (2002).

36 Duane Nash, "South Africa's Medicines and Related Substances Control Act of 1997," Berkeley Technology Law Journal 15 (2000): 485

37 Valparaíso, "Resolution for the Granting of Non-Voluntary Licenses Referred to in Article 51 No 2 of Industrial Property Law No 19.030 to Facilitate Access and Availability of Medicines and Technologies for the Prevention, Treatment and Cure of Coronavirus Covid-19," n.d., https://www.keionline.org/chilean-covid-resolution. 
Israel's turn to announce that such licenses would be granted for the lopinavir/ritonavir combination (Kaletra R), before the patentee relinquished ${ }^{38}$ its rights in march 2020. Then Ecuador passed a resolution similar to Chile's. ${ }^{39}$ Furthermore, on March 25, 2020, the Canadian Parliament passed Bill C-13 regarding specific measures in response to COVID-19, which introduces, among other things, a compulsory license during the public health emergency COVID$19 .^{40}$

\section{WHO and WTO Attempts to Facilitate Access to Vaccines in Developing Countries Covax and C-TAP Trade-offs}

The WTO and WHO have attempted to provide technical solutions to help developing countries access COVID-19 vaccines or make their own. Unfortunately, these solutions have not yet proven to be effective. One of the proposals to accelerate vaccine production, designed by the WHO, is the C- TAP program (Pooled Access to Technology against covid-19). This is a global mechanism for voluntary sharing of knowledge, data and intellectual property of health technologies for the fight against COVID-19. ${ }^{41}$ The C-Tap was established by WHO in June 2020, but no technology has been shared to date.

Another proposal has been the Covax system, which is supposed to allow for pooled procurement of Covid-19 vaccines to ensure that approximately $180^{42}$ territories have fair and equitable access to vaccines. The Covax mechanism is having difficulty getting off the ground, to the point that the WHO is now talking about $2024^{43}$ deadline. Although pharmaceutical companies developed the Covid-19 vaccines with large amounts of public money, they are selling countries, and manufacturers are trying to secure two billion doses for $190^{44}$ low- and middle-income countries.

\section{Patent Waiver and Governmental Exception to Patent Use}

The waiver of patents on COVID-19 vaccines is a way for countries in the South to gain quicker access to information on vaccine manufacturing. A patent gives the patentee an exclusive right to use his or her invention for commercial purposes, but if vaccines are made available to all, patents on these vaccines should be suspended. ${ }^{45}$ For a long time, when the world faced epidemics and pandemics, many mobilisations, especially from the South, were made for universal access to

38 Ellen 't Hoen, "Covid-19 and the Comeback of Compulsory Licensing," Medicines Law \& Policy, n.d., https://medicineslawandpolicy.org/2020/03/covid-19-and-the-come-back-of-compulsory-licensing/.

39 Jimmy Candell Soto and Raysa Vargas Secaira, "Resolution to Require the National Government to Establish Compulsory Licenses and Other Measures to Guarantee Free and Affordable Access to Pharmaceutical Products and Medical Technologies in the Declaration of Sanitary Emergency Due to the Coronavirus P," postgraduates and students of the Public Health System, n.d., https://www.keionline.org/ecuador-CL-coronavirus-resolution.

40 Parlement Canada, “COVID-19 Emergency Response," n.d. https://www.parl.ca/LegisInfo/BillDetails.aspx?Language=E\&billId= 10710867 .

41 WHO, “COVID-19 Technology Access Pool," n.d., https://www.who.int/initiatives/covid-19-technology-accesspool.

42 Aishu Balaji, "COVAX Protects the Vaccine Apartheid Status Quo," n.d., https://www.jacobinmag.com/2021/05/covid-covax-vaccine-apartheid-wto-trips-intellectual-property-ip.

43 Balaji.

44 Balaji.

45 WHO, "Waive Covid Vaccine Patents to Put World on War Footing 7 March 2021," n.d., https://www.who.int/news-room/commentaries/detail/waive-covid-vaccine-patents-to-put-world-on-war-footing. 
vaccines. In the case of the COVID-19 pandemic, India and South Africa have continuously used the WTO to cancel the property rights on vaccines. Access to health is a right for all. In addition, with Covid-19, humanity is facing a global pandemic, which will only be addressed globally, as no one is safe until everyone has access to safe and effective treatments and vaccines. Vaccines are a common good and should be managed as such.

Rapid universal access to vaccines requires consistent decisions and practices over time. This requires the suspension of patents, the development of production, the dissemination of tools and know-how, quality production everywhere, and the public financing of a public good. Last month, the announcement of the US administration to support the suspension of property rights for those against Covid- $19^{46}$ was the first success. Lifting these patents would remove legal barriers that would prevent other companies from producing these vaccines. ${ }^{47}$ This lifting of the patents would allow more doses to be manufactured at lower prices for its supporters. Nevertheless, this success is partial and fragile in the face of opposition from the European Union, Japan and the United Kingdom. According to Merkel, suspending property rights will discourage innovation, ${ }^{48}$ undermining the benefits to be gained. Secondly, these states suggest that the countries of the South $^{49}$ do not have sufficient capacity to produce vaccines. This claim is unfounded, as many generic treatment companies worldwide would be able to produce the vaccines.

In addition to the patent waiver, the government use exception is also seen as a means of rapid access to vaccines. It is a prerogative held by a state that can use a patent without the approval of the patent holder but in the public interest and for health emergencies. The principle of the use exception is quite similar to that of the compulsory license; however, their additional point that is not negligible is the rapid issuance plus the license that allows the government the right to use the pharmaceutical patent without negotiating with the holder beforehand. For example, in 2017,50 Malaysia issued a compulsory license for government use to obtain a cheaper generic version of Sofosbuvir, a well-known hepatitis C drug. This compulsory license is believed to have reduced the cost of treatment by RM1,000 to RM1,200 (US\$240 to US\$285) for a 12-week course of treatment, compared with RM300,000 (about US\$72,000) for the patented version before the license was issued.

\section{Problems to be Solved}

Even if there are significant advances, there are still many problems. Because of the limitations of Article 31(f) of the TRIPS Agreement about the use of compulsory licenses by the country that authorised the license, what can countries that do not have domestic production capacity for the drugs be subject to a compulsory license? Point 6 of the Doha Declaration asked the TRIPS

46 BBC, "Covid: US Backs Waiver on Vaccine Patents to Boost Supply," n.d., https://www.astroawani.com/beritamalaysia/using-compulsory-licence-affordable-medicines-200558.

47 BBC.

48 Reuters Staff, "Vaccine Patent Waiver Could Impact Quality of Shots -Merkel," n.d., https://www.reuters.com/article/eu-india-merkel-idUSS8N2D400S.

49 OECD, "Coronavirus (COVID-19)Vaccines for Developing Countries: An Equal Shot at Recovery," n.d., https://read.oecd-ilibrary.org/view/?ref=1060_1060300-enj5o5xnwj\&title=Coronavirus-COVID-19-vaccines-fordeveloping-countries-An-equal-shot-at-recovery\&_ga=2.5971899.909716357.16233308981992882103.1604019787.

50 Chee Yoke Ling, "Using Compulsory Licence for Affordable Medicines," n.d., https://www.astroawani.com/berita-malaysia/using-compulsory-licence-affordable-medicines-200558. 
Council to "find an early solution to this problem and report back to the General Council before the end of 2002". Several solutions are envisaged, namely: 1) either to institute a moratorium on the settlement of disputes. This is the position defended by the United States ${ }^{51}$ before the actual president support the idea about patent waiving requested by developing countries; or 2) modify Article 31 by allowing the import of a drug produced under a compulsory license by a third country with the production capacity. This is the solution advocated by the European Commission, ${ }^{52}$ which provides for a rigorous framework for this exception to avoid any slippage: the drug should not be placed on the market of the producing country but only exported to the country covered by the compulsory licence, without the possibility of re-exporting to another country; the rights holder should have the opportunity to offer production of the products at a reduced price and, if this price is not low enough, he would be permanently informed of the authorisation procedure relating to the compulsory licence; the producing country and the importing country should take all reasonable and necessary measures in order to allow the respect of these conditions This system should be applied as a priority to drugs for the treatment of AIDS, tuberculosis, malaria and other epidemics and pandemics such as COVID-19 that the world is facing today. The purpose of this strict control of the conditions for issuing compulsory licenses is to prevent reexport to other countries and thus the use of compulsory licenses for industrial policy purposes rather than public health. Some companies, however, have entered into negotiations with certain countries to sell them drugs at prices that are far below those charged in industrialised countries. The European Commission and France, in particular, support this policy of differentiated pricing to reduce the price of drugs for developing countries.

\section{CONCLUSION}

This article has attempted to put the recent WTO efforts to provide access to medicines in developing countries into historical context. By examining the patent history and the different intellectual property regimes that existed for medicines before TRIPS came into force, we believe it is easier to understand how TRIPS strengthens the international intellectual property protection regime, particularly in the pharmaceutical area. We can also better understand why the WTO's efforts, while laudable, fall far short of restoring the ability of WTO Member States to take into account the public health considerations that they value. HIV/AIDS, VCT-19, malaria and tuberculosis are global tragedies. Citizens of developing countries suffer particularly from high drug prices imposed by companies holding patents. However, these cases should not make us forget that the cost of drugs, which is responsible for a large part of the increase in health care costs and the increase in insurance costs, also affects the citizens of so-called developed countries, to the point of becoming prohibitive at times. The availability of safe and effective vaccines against COVID19 is the best way to overcome the pandemic. Concern about the evolution of the pandemic, particularly in low- and middle-income countries, reminds us that the COVID-19 pandemic is not yet over and that a new vaccine will need to be developed to combat mutations. The international

51 "2nd US Communication on Paragraph 6 of the Doha Declaration on the TRIPS Agreement and Public Health, 25 June 2002, Document IP/C/W/358 Available on the WTO Website: "a Moratorium on Dispute Settlement [...] Is More Likely to Lead to an Expeditious, Worka," n.d.

52 "Communication of the EC Member States to the TRIPS Council Relating to Paragraph 6 of the Doha Declaration on the TRIPS Agreement and Public Health, Bruxelles, 18 Juin 2002,” n.d. 
community is expected to develop exceptional solutions related to the increase of COVID-19 vaccine production and the global geographic distribution of production capacity. Considering that the TRIPS agreement does not specify the reasons that could justify the use of compulsory licenses and that the declaration on public health adopted in Doha on November 14, 2001, in its fourth point indicates that the TRIPS agreement should be implemented and interpreted in a manner favourable to public health, the WTO is expected to facilitate the use of compulsory licenses, in order to guarantee rapid access to vaccine production worldwide. The WTO is expected to facilitate the use of compulsory licensing to ensure rapid access to vaccine production worldwide, to ensure the quality, safety and efficacy of vaccines, and to ensure that all countries have equitable access to vaccines at an affordable price as soon as possible - in other words, to eliminate all the root causes of non-access to vaccines.

\section{REFERENCES}

Anderson, Brin. "Better access to medicines: Why Countries are Getting "tripped" up and not ratifying article 31 bis", Case Western Reserve Journal of Law, Technology \& the Internet (2010).

Attaran, Paul Champ and Amir. "Patent Rights and Local Working Under the WTO Trips Agreement: An Analysis of the U.S.-Brazil Patent Dispute." Yale Journal of International Law 27 (2002).

Balaji, Aishu. "COVAX Protects the Vaccine Apartheid Status Quo," n.d. https://www.jacobinmag.com/2021/05/covid-covax-vaccine-apartheid-wto-trips-intellectualproperty-ip .

BBC. "Covid: US Backs Waiver on Vaccine Patents to Boost Supply," n.d. https://www.astroawani.com/berita-malaysia/using-compulsory-licence-affordablemedicines-200558.

Canada - Patent Protection for Pharmaceutical Products (Complaint by the European Communities and their Member States), (2000) WTO Doc.WT/ DS114/R Panel Report para 4.21 page37.

Cassier, Maurice. "Industrial Property and Public Health. Project Magazine, Centre for Social Research and Action; in French, Pro-Priété Industrielle et Santé Publique. Revue Projet, Centre de Recherche et d'action Sociales (C.E.R.A.S )" 270, no. 2 (2002). https://halshs.archives-ouvertes.fr/halshs-01893992/document.

"Communication of the EC Member States to the TRIPS Council Relating to Paragraph 6 of the Doha Declaration on the TRIPS Agreement and Public Health, Bruxelles, 18 Juin 2002," n.d.

Doha WTO Ministerial. "TRIPS WT/MIN(01)/DEC/2 20 November 2001.Declaration on the TRIPS Agreement and Public Health Adopted on 14 November 2001," 2001. https://www.wto.org/english/thewto_e/minist_e/min01_e/mindecl_trips_e.htm.

England's Statute of Monopolies of 1623 (21 Jac. 1, c.3), while generally condemning monopolies, provided the true and first inventor of a given item up to fourteen years of exclusive rights to their invention, provided that: ..."they be not contrary to $t$ (n.d.). https://en.wikisource.org/wiki/Statute_of_Monopolies .

Etat, Gabriel Galvez-behar L, and Gabriel Galvez-behar. "L'Etat et l'invention. Une Comparaison Franco-Allemande Des Cadres de La Propriété Industrielle à La Fin Du XIXè Siècle.," 2010, 34. https://halshs.archives-ouvertes.fr/halshs-00010217/document . 
Gervais, D. The TRIPS Agreement: Drafting History and Analysis, Londres, Sweet \& Maxwell (1998).

Henderson, Gordon F. Patent Law of Canada, (Toronto, Carswell, 1997) (1997).

Hindle, Richard L. "Inventing Venice: An Urban and Environmental Innovation Model from the Lagoon City." UC Berkeley, 2019, 531. https://escholarship.org/uc/item/75635711.

Hoen, Ellen 't. "Covid-19 and the Comeback of Compulsory Licensing." Medecines Law \& Policy, n.d. https://medicineslawandpolicy.org/2020/03/covid-19-and-the-come-back-ofcompulsory-licensing/. .

Klod, Olia i. "Pour Tout Savoir Sur Venise, Le Carnaval Vénitien et Les Costumé-E," 2011. https://oliaklodvenitiens.wordpress.com/2011/03/19/parte-veneziana/ .

Lapointe, Serge. "L’histoire Des Brevets," 2000. https://www.lescpi.ca/s/1972. .

Ling, Chee Yoke. "Using Compulsory Licence for Affordable Medicines," n.d. https://www.astroawani.com/berita-malaysia/using-compulsory-licence-affordablemedicines-200558 .

Mappian, Émilie Bouchet-Le. "Intellectual Property and Property Law in English, German and French Law. In French; Propriété Intellectuelle et Droit de Propriété En Droits Anglais, Allemand et Français." Presses universitaires de Rennes. Presses universitaires de Rennes, 2013.

Marre, V. B. “Rapport d'information Déposé Par La Délégation de l'Assemblée Nationale Pour l'Union Européenne Sur Le Bilan de La Conférence Ministérielle de l'OMC de Doha, 31 Janv," 2002.

Mfuka Claude, TRIPS and pharmaceutical patents. "The Difficult Access of Developing Countries to AIDS Drugs Page 194, in French Accords ADPIC et Brevets Pharma-Ceutiques : Le Difficile Accès Des Pays En Développement Aux Médicaments Antisida. In." Revue d'économie Industrielle 99, no. 2 (2002): 191-214.

Nash, Duane. "South Africa's Medicines and Related Substances Control Act of 1997." Berkeley Technology Law Journal 15 (2000): 485.

O Mitnovetski, D Nicol. “Are Patents for Methods of Medical Treatment Contrary to the Ordre Public and Morality or 'Generally Inconvenient'?" Journal of Medical Ethics 30, no. 5 (2004): 470. https://doi.org/10.1136/jme.2002.000786.

OECD. "Coronavirus (COVID-19)Vaccines for Developing Countries: An Equal Shot at Recovery," n.d. https://read.oecd-ilibrary.org/view/?ref=1060_1060300enj5o5xnwj\&title=Coronavirus-COVID-19-vaccines-for-developing-countries-An-equalshot-at-recovery\&_ga=2.5971899.909716357.1623330898-1992882103.1604019787 .

Organisation, World Health (WHO). "Fifty-Second World Health Assembly." Fifty-Second World Health Assembly, Geneva, 17-25 May 1999: Verbatim Records of Plenary Meetings and List of Participants. 52, no. 8649 (1999): 26.

Parlement Canada. "COVID-19 Emergency Response," n.d. https://www.parl.ca/LegisInfo/BillDetails.aspx?Language=E\&billId= 10710867 .

Provisions, Annex I Patents Title I General. African Intellectual Property Organization (OAPI) Bangui Agreement (n.d.).

Rathod, Sandeep K. "Compulsory Licences on Pharmaceutical Patents in India: A Short Article.” 
Journal of Generics Medecines 13 (2017): 108.

Remiche, Desterbecq H. et B. Les brevets pharmaceutiques dans les accords du GATT : l'enjeu ?, Revue internationale de droit économique, X (1) (1996).

- pharmaceutical patents in the GATT agreements: what is at stake? page 18, in french Les brevets pharmaceu-tiques dans les accords du GATT : l'enjeu ?, Revue internationale de droit économique, X (1) (1996).

Salazar, S. "Panel Discussion on Intellectual Property and Human Rights, Organised by the World Intellectual Property Organization Intellectual Property Organization (WIPO) Geneva." Intellectual Property and the Right to Health, no. 762 (1999): 65-91, 71.

Scherer, F. The patent system and innovation in the pharmaceutical field, in french, Le système des brevets et l'innovation dans le domaine pharmaceutique, Revue Internationale de Droit Economique, $\mathrm{n}^{\circ} 1$ (2000).

Secaira, Jimmy Candell Soto and Raysa Vargas. "Resolution to Require the National Government to Establish Compulsory Licenses and Other Measures to Guarantee Free and Affordable Access to Pharmaceutical Products and Medical Technologies in the Declaration of Sanitary Emergency Due to the Coronavirus P." postgraduates and students of the Public Health System, n.d. https://www.keionline.org/ecuador-CL-coronavirus-resolution.

Sidley, Pat. "Drug Companies Sue South African Government over Generics." BMJ 24, no. 332 (2001): 447. https://doi.org/doi: 10.1136/bmj.322.7284.447.

Staff, Reuters. "Vaccine Patent Waiver Could Impact Quality of Shots -Merkel," n.d. https://www.reuters.com/article/eu-india-merkel-idUSS8N2D400S.

the authorisation is given for the internal market of the Member State that allowed the use; the scope and duration of the authorisation are limited; the compulsory license is not transferable; the patent holder must receive adequate remuneration, etc. "The Patent Holder Must Have Refused a Voluntary License," n.d.

Thomann, Dirk De Bièvre Lars. Forum Shopping in the Global Intellectual Property Rights Regime, Arbeitspapiere - Working Papers Nr. 132, Mannheimer Zentrum für Europäische Sozialforschung (2010).

TRIPS Agreement.

Tsai, George. Canada's Access to Medicines Regime: Lessons for Compulsory Licensing Schemes under the WTO Doha Declaration, 49 VA. J. INT'L L. (2009).

Valparaíso. "Resolution for the Granting of Non-Voluntary Licenses Referred to in Article 51 No 2 of Industrial Property Law No 19.030 to Facilitate Access and Availability of Medicines and Technologies for the Prevention, Treatment and Cure of Coronavirus Covid-19," n.d. https://www.keionline.org/chilean-covid-resolution.

WHO. “COVID-19 Technology Access Pool," n.d. https://www.who.int/initiatives/covid-19technology-access-pool .

. "Waive Covid Vaccine Patents to Put World on War Footing 7 March 2021," n.d. https://www.who.int/news-room/commentaries/detail/waive-covid-vaccine-patents-to-putworld-on-war-footing.

WTO. "Implementation of Paragraph 6 of the Doha Declaration on the TRIPS Agreement and Public Health, 30 August 2003, WT/GC/M/82," n.d. https://www.wto.org/english/tratop_e/trips_e/implem_para6_e.htm . 
- "Protocol Amending the TRIPS Agreement, WT/L/540," n.d. https://www.wto.org/french/tratop_f/trips_f/implem_para6_f.htm .

—. "Statistical Review of World Trade 2020." Figure 4.34 Top 20 exporters of chemicals and pharmaceuticals, 2016. https://www.wto.org/french/res_f/statis_f/wts2016_f/wts2016_f.pdf .

2nd US Communication on Paragraph 6 of the Doha Declaration on the TRIPS Agreement and Public Health, 25 June 2002, Document IP/C/W/358. 